Proceedings

\title{
Seasonal Abundance Changes of Spotted Wing Drosophila in Neighbouring Habitats in Hungary ${ }^{\dagger}$
}

\author{
Ferenc Deutsch ${ }^{1,2, *}$ and Balázs Kiss ${ }^{2}$
}

Citation: Deutsch, F.; Kiss, B. Seasonal Abundance Changes of Spotted Wing Drosophila in Neighbouring Habitats in Hungary, in Proceedings of the 1st International Electronic Conference on Entomology, 1-15 July 2021, MDPI: Basel, Switzerland, doi:10.3390/IECE10488

Published: 1 July 2021

Publisher's Note: MDPI stays neutral with regard to jurisdictional claims in published maps and institutional affiliations.

Copyright: () 2021 by the authors. Submitted for possible open access publication under the terms and conditions of the Creative Commons Attribution (CC BY) license (http://creativecommons.org/licenses /by/4.0/).
${ }^{1}$ Hungarian University of Agriculture and Life Science; deutsch.ferenc@hallgato.uni-szie.hu

2 Plant Protection Institute, Centre for Agricultural Research; ELKH; kiss.balazs@atk.hu

* Correspondence: deutsch.ferenc@atk.hu;

+ Presented at the 1st International Electronic Conference on Entomology (IECE 2021), 1-15 July 2021; Available online: https://iece.sciforum.net/.

\begin{abstract}
The invasive spotted wing drosophila (SWD - Drosophila suzukii (Matsumura, 1931)) became an important pest in several parts of Europe in less than one decade. High variations are reported by geographical regions in the phenology of the species and thus in the damages in different soft-skinned fruits. Our study aimed to compare phenological patterns of SWD in various neighbouring habitats (cherry/sour cherry and blackberry plantations, forested and built-up areas) in a hilly berry production region of Hungary (Nógrád county). The investigation consisted of operating 16 bottle traps (with vinegar and red wine) on eight spots during four years (2017-2020). The traps in cherry/sour cherry plantations caught the highest number of SWD ( $n=21997)$, which was followed by forests $(n=20616)$, built-up areas $(n=10567)$ and blackberry plantations $(n=5035)$. No substantial differences were found in phenological patterns between the habitat types in any year; the catches did not reflect the lack of ripening fruits. The highest numbers of SWD imagoes were caught in September and October, while virtually no SWD individuals were caught before July. The lack of SWD catches in the first half of the year suggests that long-distance migration may play an essential role in the population dynamic of SWD by re-establishing pest populations regularly in mid-summer in Hungary.
\end{abstract}

Keywords: phenology; landscape; migration; fruit pest; Drosophila suzukii

\section{Introduction}

The invasive spotted wing drosophila (SWD - Drosophila suzukii (Matsumura, 1931)) was firstly detected in Europe and North America in 2008. The pest has invaded most part of the continent in less than one decade, and since then, it causes sensible damages to various soft-skinned fruits [1]. In Hungary, the pest was firstly detected in a motorway rest area in 2012. For 2014, the species already occurred in high numbers in the whole country [2], and the first damage was also reported from a raspberry plantation [3]. Since then, economically sensible damages are regularly reported from different berry cultures [4].

The polyphagous SWD occurs in surprisingly high abundance in a wide range of habitats, including places that do not provide suitable fruits for the development of the larvae. The mass migration of the imagoes between the different habitats within the landscape is a key factor in the pest's harmfulness. The migration activity of SWD was studied from multiple aspects. The seasonal vertical migration SWD from the valleys to mountainous areas to avoid unsuitable temperatures was proved by Calabria et al. (2012) and Stockton et al. (2018). The effect of the vicinity of the forested regions on the abundance of SWD in the crops was demonstrated by several authors [7, 8, 9]. Swoboda-Bhattarai [10] investigated the daily activity pattern of SWD movement between crop and neighbouring noncrop habitats. SWD was found to change between fruit orchards ripening in 
different times, namely to move from mid-summer to the fig, apricot, pear orchards, and from the beginning of autumn to the citrus and noncrop areas [11].

Our work aimed to compare phenological patterns of SWD in neighbouring crop (cherry/sour cherry and blackberry plantation) and noncrop (forested and urban areas) habitats to better understand the pest's migratory activity.

\section{Materials and methods}

The investigation took place in two locations (Berkenye: $\mathrm{N} 47.886554^{\circ}, \mathrm{E} 19.071036^{\circ}$, Romhány: $\mathrm{N} 47.918868^{\circ}$, E $\left.19.263236^{\circ}\right) 50 \mathrm{~km}$ from each other in Nógrád county (Hungary), a hilly berry production region. The trapping spots were appointed in four neighbouring habitats beside the two villages: built-up area (village centres), cherry (Romhány) /sour cherry (Berkenye) orchards (hereinafter cherry orchards), blackberry orchards, forested area. We placed two bottle traps per trapping spots; therefore, 16 traps were operating during the survey. The traps were made of $500 \mathrm{ml}$ plastic bottles, with 16 holes on the upper side $(\mathrm{d}=0,5 \mathrm{~mm})$. We used $150 \mathrm{ml} 5 \mathrm{~V} / \mathrm{V} \%$ commercial apple cider vinegar as a lure in traps. The survey lasted from April 2017 to November 2020, and the traps were replaced monthly. The traps were carried to the laboratory, and the content was checked under binocular stereo microscope. SWD imagoes were distinguished by sex and morphs (summer and winter morph), and the other flies belonging to Drosophilidae were also counted. For the identification, we used the key from [12].

\section{Results}

The highest D. suzukii catches were observed in the cherry orchards and forested areas each year. On the other hand, the catches were surprisingly low in blackberry plantations as they were even lower than the catches in built-in areas (Table 1). Furthermore, an important difference was found between years in the total number of $D$. suzukii caught by the traps, namely the catches in 2017 were lower by close to one magnitude than in the following years, while in 2019, the catches were several times higher than in 2018 or 2020. However, the outstanding catch values of 2019 were solely due to the catches of forest habitats and cherry plantations. On the contrary, in built-in areas and the blackberry plantations, no such salience was observed (Figure 1).

Table 1. Total catches of spotted wing drosophila and other drosophilid flies by habitat types.

\begin{tabular}{|l|r|r|r|r|r|r|}
\hline & \multicolumn{1}{|c|}{$\begin{array}{c}\text { SWD } \\
\text { winter } \\
\text { morphs } \\
\text { habitat }\end{array}$} & $\begin{array}{c}\text { SWD } \\
\text { summer } \\
\text { morphs } \\
\text { male }\end{array}$ & $\begin{array}{c}\text { SWD } \\
\text { winter } \\
\text { morphs } \\
\text { female }\end{array}$ & $\begin{array}{r}\text { SWD } \\
\text { summer } \\
\text { morphs } \\
\text { female }\end{array}$ & $\begin{array}{c}\text { SWD in } \\
\text { total }\end{array}$ & $\begin{array}{r}\text { other } \\
\text { Drosophilids }\end{array}$ \\
\hline forest & 1438 & 7718 & 1487 & 9972 & 20616 & 18948 \\
\hline built-up area & 703 & 4595 & 692 & 4577 & 10567 & 7382 \\
\hline cherry orchards & 806 & 8900 & 821 & 11469 & 21997 & 12195 \\
\hline blackberry & 546 & 1870 & 590 & 2029 & 5035 & 2997 \\
\hline
\end{tabular}



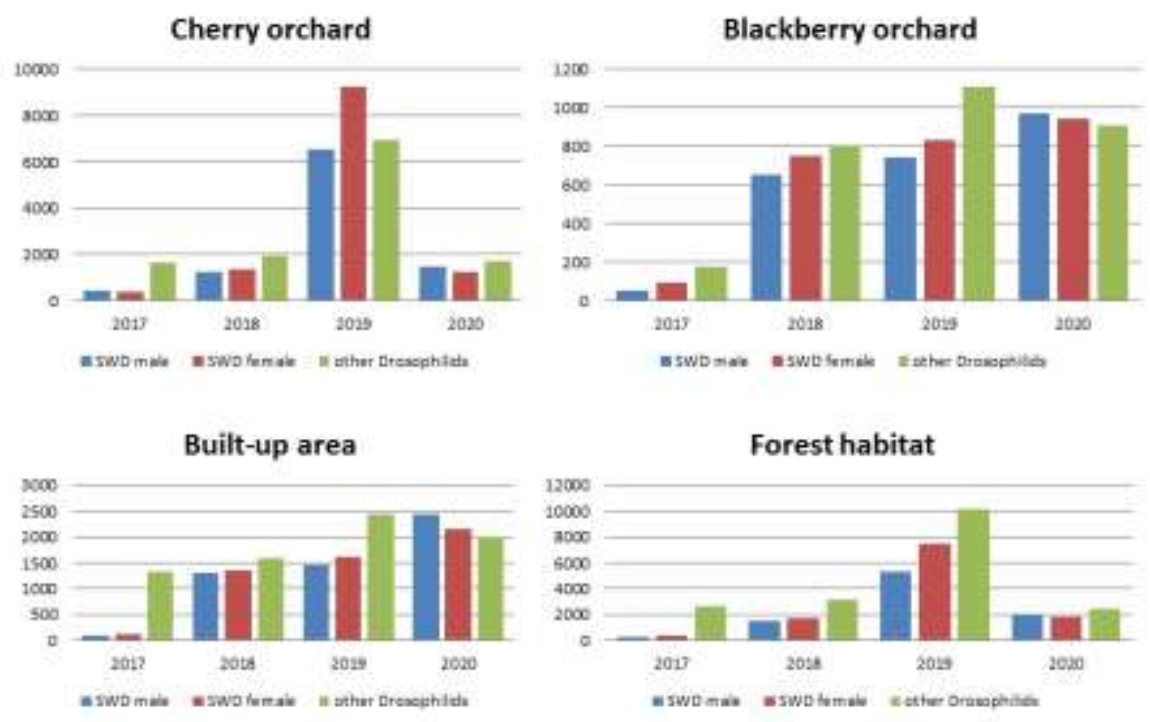

Figure 1. Total yearly catches of spotted wing drosophila and other drosophilids by habitats.

The seasonal pattern of SWD catches was similar in the different habitats, irrespectively from the presence of ripening fruits in the parcels. No SWD imagoes were in the traps in the spring months (March, April, May), and only a negligible number of individuals were caught in June. The catches started to increase in July, and the highest numbers were found in September and October (Figure 2). SWD imagoes were found in the traps until severely cold periods occurring in different winter months in the years. The winter morphs appeared in the traps in September $(2019,2020)$ or in October $(2017,2018)$, and they reached $70-80 \%$ of SWD imagoes in November.

The sex ratio of SWD imagoes was close to $50 \%$ for the total SWD catches, and it did not change substantially between the years or habitats; the proportion of males in the forested and built-up area, cherry and blackberry plantation were 44\%, $50 \%, 44 \% 48 \%$, respectively.

Drosphilids, other than SWD, were present in the traps in significant numbers also in the first half of the year, but they were largely outnumbered from August and September by SWD. The proportion of latter reached even $80 \%$ in the autumnal samples. 


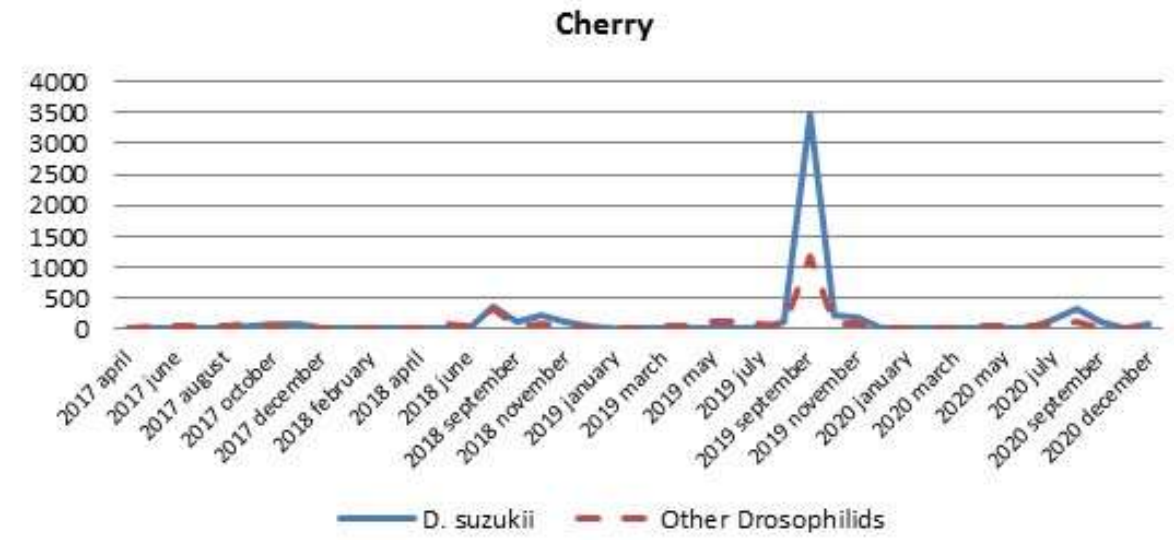

Blackberry

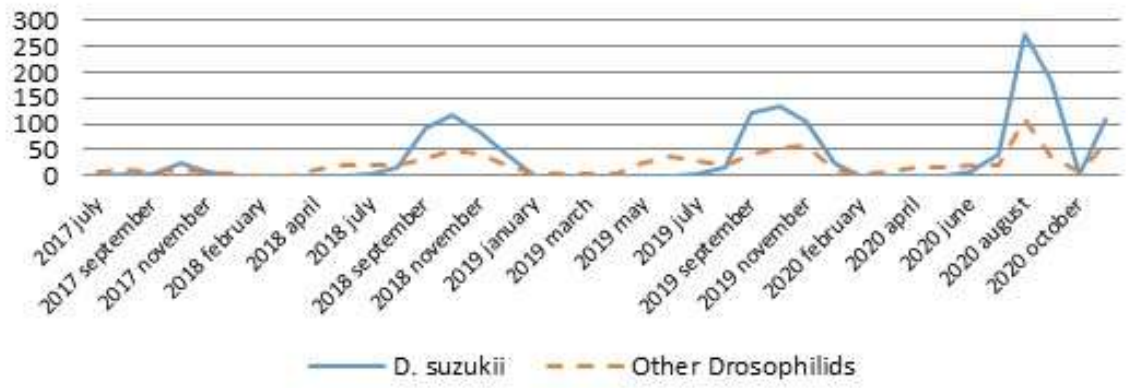

Forested

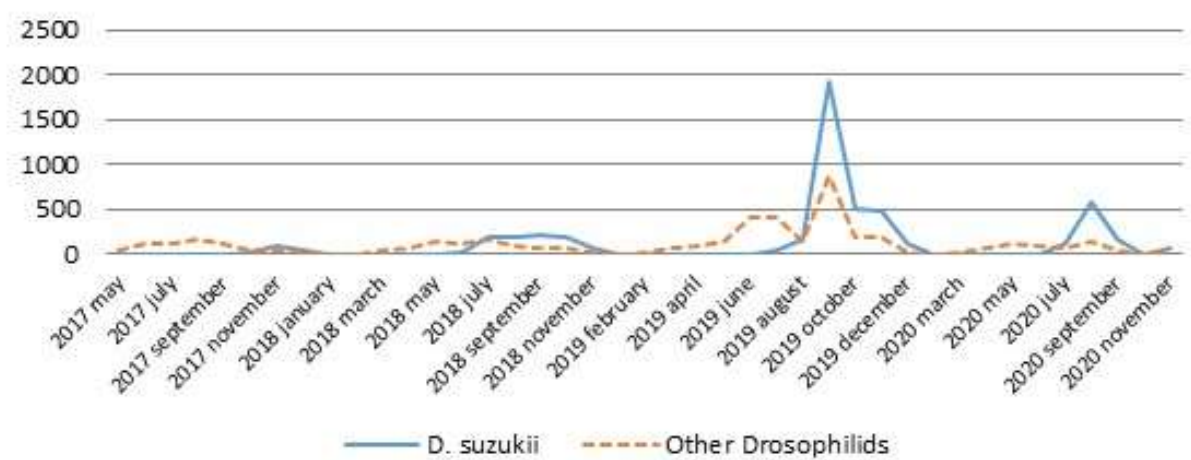

Built-up area

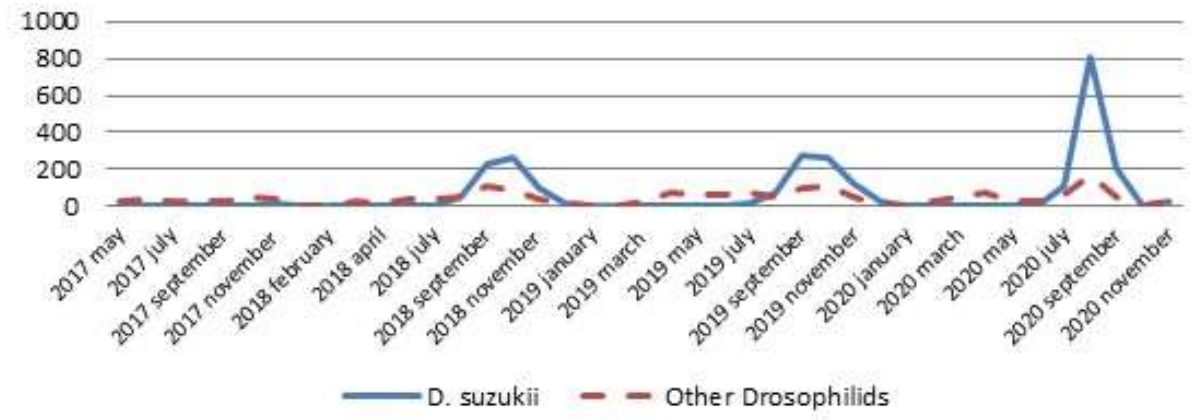

Figure 2. Monthly catches of spotted wing drosophila and other drosophilids by trap in different habitats. 


\section{Discussion}

Despite its invasion success, SWD is relatively less resistant to temperature extremes and dryness [13]. This sensibility may explain some unexpected results. For example, the lower overall catches in blackberry plantations, where the ripening fruits are available until mid-autumn, probably are due to the open structure of the plantation exposed to sun and dryness. The low catches of the year 2019 may reflect the higher temperatures and low precipitation in the summer months compared to the following years. In the cherry plantations, the high catches occurred in periods where no suitable fruits were available for SWD, implying that cherry plantations provide suitable microclimatic conditions for $\mathrm{SWD}$, the same way as forested areas, irrespectively of fruit production.

In contrast with the absolute numbers, we could not find any substantial differences in the seasonal changes of trap results between the different habitats, and we could not demonstrate mass migrations between the territories.

The complete lack of SWD catches before June suggests that, due to low winter temperatures, the overwintering of SWD is highly limited in Hungary, similarly to other northern or continental parts of Europe. Consequently, long-distance migration from the Mediterranean region may play an essential role in the population dynamic of SWD by re-establishing pest populations regularly in mid-summer in Hungary.

Acknowlegement: The study was financially supported by NKFIH grant (k119844).

\section{References}

1. Asplen, M. K., Anfora, G., Biondi, A., Choi, D., Chu D., Daane, K. M., Gibert, P., Gutierrez, A. P., Hoelmer, K. A., Hutchison, W. D., Isaacs, R., Jiang, Z., Kárpáti, Z., Kimura, M.T., Pascual M., Philips, C. R., Plantamp, C., Ponti, L., Vétek, G., Vogt, H., Walton, V. M., Yu Y., Zappala, L., Desneux, N. Invasion biology of spotted wing Drosophila (Drosophila suzukii): a global perspective and future priorities. Journal of Pest Science 2015 DOI 10.1007/s10340-015-0681-z

2. Kiss, B., Kis, A., Vassné, K.Á. The rapid invasion of spotted wing drosophila, Drosophila suzukii (Matsumura) (Diptera: Drosophilidae), in Hungary. Acta Phytoparasitica 2016 44(3). DOI: 10.1007/s12600-016-0520-7

3. Veszelka, M., Pesti, J-né, Zagyvai, D. A pettyesszárnyú muslica - Drosophila suzukii (Matsumura 1931) 2014-2015. évi csapdázásának tapasztalatai Nógrád megyében. Integrált termesztés a kertészeti és szántóföldi kultúrákban (XXXII.), Budapest (Conference proceeding), 2015 p: 121-124

4. Kiss, B., Kákai, Á, Szántóné, V.M., Pesti, J., Kárpáti, Zs., Molnár, B.P., Vétek, G. A pettyesszárnyú muslica (Drosophila suzukii) kártétele Magyarországon 2016-ban, Conference Proceeding 63th. Növényvédelmi Tudományos Napok. 2017 p. 85

5. Calabria, G., Máca, J., Bächli, G., Serra, L., Pascual, M. First records of the potential pest species Drosophila suzukii (Diptera: Drosophilidae) in Europe, Journal of Applied Entomology, 2016, 136(2012), pp:139-147

6. Stockton, G.D., Wallingford, K.A., Loeb, M.G. Phenotypic Plasticity Promotes Overwintering Survival in A Globally Invasive Crop Pest Drosophila suzukii, Insects, 2018, 9/105 pp: 1-16

7. Klick, J., Yang, W.Q., Walton, V.M., Dalton, D.T., Hagler, J.R., Dreves A.J., Lee, J.C., Bruck, D.J. Distribution and activity of Drosophila suzukii in cultivated raspberry and surrounding vegetation, Journal of Applied Entomology, 2016, 140, pp: 37-46

8. Hennig, I.E., Mazzi, D. Spotted wing Drosophila in sweet cherry orchards in relation to forest characteristics, bycatch, and resource availability. Insects, 2018, 9,118 DOI p:22

9. Pelton, A:, Gratton, C., Isaacs, R., Van Timmeren, S., Blanton, A., Guédot, C. Earlier activity of Drosophila suzukii in high woodland landscapes but relative abundance is unaffected. Journal of Pest Science, 2016, 89. pp: 725-733

10. Swoboda-Bhattarai, K., Burrack, H. Diurnal and seasonal activity patterns of Drosophilid Species (Dipterarosophilidae) present in blackberry agroecosystems with a focus on Spotted-wing Drosophila. Environmental Entomology, 2020, doi: 10.1093/ee/nvz161 pp:11 
11. Wang, X., Stewart, J.T., Biondi, A., Chavez, A.B., Ingels, C., Caprile, J., Grant, A.J., Walton, M.V., Daane, M.K. Population dynamics and ecology of Drosophila suzukii in Central California. Journal of Pest Sciences, 2016, 2016/89 pp:701-712

12. Bächli, G., Vilela, C.R., Escher, A.S., Saura, A. The Drosophilidae (Diptera) of Fennoscandia and Denmark. Fauna Entomologica Scandinavica, 2004, vol. 39. Brill, Leiden pp: 362

13. Kimura, M. Cold and heat tolerance of Drosophilid flies with reference to their latitudinal distributions. Oecologia, 2004, 140: 442-449. 